\title{
Respon Eksplan Batang Kentang (Solanum tuberosum L.) terhadap Perlakuan Konsentrasi Thidiazuron (TDZ) pada Media MS secara In Vitro
}

\section{Response of Potato Stem Explants (Solanum tuberosum L.) to Thidiazuron (TDZ) Concentration Treatment in MS Media In Vitro}

\author{
Jefri Saputro*, Nintya Setiari, Yulita Nurchayati, Munifatul Izzati \\ Program Studi Biologi Fakultas Sains dan Matematika Universitas Diponegoro \\ *Email : jefrisaputro100@gmail.com
}

Diterima 13 Juli 2020/Disetujui 20 September 2020

\begin{abstract}
ABSTRAK
Kentang (Solanum tuberosum L.) merupakan komoditas yang berpotensi dalam diversifikasi pangan, namun perbanyakan bibit dengan umbi tidak efektif untuk persediaan bibit nasional. Solusi dari permasalahan tersebut adalah perbanyakan dengan kultur jaringan melalui teknik organogenesis. Penelitian ini bertujuan untuk mengetahui dan menganalisis jenis eksplan dan konsentrasi TDZ yang tepat untuk meningkatkan respon viabilitas dan organogenesis eksplan. Metode yang digunakan adalah induksi organogenesis. Eksplan batang dipotong melintang dan diinisiasi dalam media MS dengan konsentrasi TDZ berbeda. Desain penelitian ini menggunakan Rancangan Acak Lengkap (RAL) pola faktorial 2x4. Faktor pertama adalah jenis eksplan (batang tanpa tunas atau B0 dan batang bertunas atau B1), dan faktor kedua adalah konsentrasi TDZ (0ppm atau T0, 4,5ppm atau T4,5, 6ppm atau T6 dan 7,5ppm atau T7,5). Parameter yang diamati adalah persentase eksplan steril, persentase eksplan hidup, jumlah tunas, jumlah daun dan jumlah akar. Hasil penelitian menunjukkan bahwa jenis eksplan batang bertunas cenderung meningkatkan viabilitas dan persentase eksplan hidup daripada jenis eksplan batang tanpa tunas, sedangkan peningkatan konsentrasi TDZ cenderung menurunkan viabilitas dan persentase eksplan hidup. Jenis eksplan dan konsentrasi TDZ mempengaruhi secara nyata jumlah tunas, daun dan akar. Peningkatan konsentrasi TDZ sampai 4,5ppm merupakan konsentrasi optimal dalam meningkatkan jumlah tunas dan daun.
\end{abstract}

Kata kunci : Solanum tuberosum, TDZ, jenis eksplan, viabilitas, organogenesis

\begin{abstract}
Potatoes (Solanum tuberosum L.) are potential commodities in food diversification, but seedling with tubers is not effective for national seed supply. The solution to these problems is propagation by tissue culture through organogenesis techniques. This study aims to determine and analyze the types of explants and TDZ concentrations that are appropriate to improve the viability and organogenesis of explant responses. The method used is organogenesis induction. Stem explants are cut transversely and initiated in MS media with different TDZ concentrations. The design of this study uses a Completely Randomized Design (CRD) $2 \times 4$ factorial pattern. The first factor is the type of explant (stem without shoots or B0 and stem shoots or B1), and the second factor is TDZ concentration (0ppm or T0, 4.5ppm or T4,5, 6ppm or T6 and 7.5ppm or T7,5). The parameters observed were the percentage of sterile explants, the percentage of live explants, number of shoots, number of leaves and number of roots. The results showed that the type of shoot explant of shoots tends to increase viability and percentage of live explants than explant types without shoots, while increasing TDZ concentration tends to decrease viability and percentage of live explants. The type of explant and TDZ concentration significantly affect the number of shoots, leaves and roots. Increasing the concentration of TDZ to $4.5 \mathrm{ppm}$ is the optimal concentration in increasing the number of shoots and leaves.
\end{abstract}

Keywords : Solanum tuberosum, TDZ, type of explant, viability, organogenesis 


\section{PENDAHULUAN}

Salah satu tanaman sumber karbohidrat di Indonesia adalah tanaman kentang yang berpotensi dalam diversifikasi pangan. Kentang biasanya tumbuh pesat di dataran tinggi dan dimanfaatkan untuk berbagai olahan pangan. Oleh karena itu tanaman kentang merupakan salah satu komoditas yang menjadi prioritas pengembangan lembaga penelitian dan pemerintah (Karjadi dan Buchory, 2008). Permintaan komoditas kentang yang meningkat mengakibatkan meningkatnya kebutuhan akan bibit kentang dalam jumlah yang besar, namun di Indonesia teknik perbanyakan bibit masih menggunakan umbi kentang. Hal ini tidak efektif untuk persediaan bibit dalam skala nasional, karena pembibitan menggunakan umbi akan membutuhkan waktu dan biaya yang besar. Perbanyakan tanaman secara konvensional menggunakan umbi akan meningkatkan infeksi penyakit pada bibit.

Adapun solusi dari pembibitan kentang yang lebih efisien adalah menggunakan teknik kultur jaringan dengan memanfaatkan eksplan kentang, seperti biji, daun, atau batang. Solusi ini sekaligus sebagai langkah menghindari ketergantungan terhadap impor serta upaya pengembangan dan pemuliaan bibit kentang, agar bibit yang dihasilkan bermutu dan bebas penyakit. Menurut Darini (2012) kultur in vitro juga dapat menghasilkan jumlah bibit tumbuhan yang banyak dalam waktu yang relatif singkat. Teknik kultur in vitro yang dilakukan dalam penelitian ini adalah teknik organogenesis. Organogenesis adalah proses pembentukan organ, baik tunas atau akar. Tanaman telah diperbanyak melalui organogenesis langsung untuk memperbaiki tingkat multiplikasi, produksi tanaman transgenik, dan perbanyakan klon. Teknik organogenesis melalui induksi tunas aksiler atau inisiasi multiplikasi tunas sering digunakan untuk perbanyakan, karena menghasilkan planlet yang seragam, tanpa variasi genetik, tingkat mutasi relatif rendah, dan memiliki nilai ekonomi yang tinggi (Bhatia, et al., 2015).

Penelitian sebelumnya oleh Aprilia (2019) menggunakan BAP 0, 1, 2, 3 ppm dan 2,4 D 0,1 ppm masih menunjukkan hasil pertumbuhan organ yang kurang optimal. Adapun penelitian ini menggunakan ZPT berupa thidiazuron (TDZ) untuk menginduksi organogenesis eksplan batang kentang in vitro. Thidiazuron digunakan sebagai zat pengatur tumbuh untuk organogenesis dikarenakan TDZ lebih efektif dalam mempercepat pembelahan sel dan merangsang multiplikasi tunas. Menurut Bilal et al., (2011) TDZ berperan dalam menstimulasi produksi sitokinin endogen dan berperan sebagai inhibitor sitokinin oksidase yang menyebabkan inaktivasi sitokinin tipe adenin bebas. Oleh karena itu TDZ dapat meningkatkan kerja sitokinin lain, baik sitokinin eksogen ataupun sitokinin endogen. Penelitian ini menggunakan sitokinin tunggal berupa TDZ tanpa kombinasi dikarenakan eksplan batang kentang yang diinisiasi diduga mengandung auksin endogen yang tinggi. TDZ telah dilaporkan efektif untuk regenerasi in vitro anggrek Dendrobium (Sujjaritthurakarn dan Kanchanapoom, 2011). Hasil penelitian Winarto, et al., (2010) menunjukkan bahwa pembentukan tunas terbaik pada kultur anther anthurium diperoleh pada kombinasi TDZ 1 ppm dan 2,4-D 0,5 ppm.

Kombinasi konsentrasi TDZ dan jenis eksplan batang kentang diharapkan mampu menginduksi organogenesis kentang secara optimal dan memberikan hasil yang lebih baik dari penelitian sebelumnya. Oleh karena itu, penelitian ini bertujuan untuk mengetahui dan menganalisis respon viabilitas dan organogenesis eksplan pada perlakuan jenis eksplan dan konsentrasi TDZ yang berbeda.

\section{METODE PENELITIAN}

Penelitian dilaksanakan di Laboratorium Kultur Jaringan, Laboratorium Biologi Struktur dan Fungsi Tumbuhan, Departemen Biologi, Fakultas Sains dan Matematika, Universitas Diponegoro. Penelitian dimulai pada bulan September 2019 sampai Februari 2020. Penelitian ini menggunakan rancangan acak lengkap (RAL) pola faktorial $2 \times 4$ dengan enam ulangan. Faktor pertama adalah jenis eksplan batang yaitu batang bertunas atau bagian nodus (B1) dan batang tanpa tunas atau internodus (B0). Faktor kedua adalah konsentrasi TDZ pada media yaitu 0 ppm (T0); 4,5 ppm (T4,5); 6 ppm (T6); dan 7,5 ppm (T7,5). Rancangan percobaan secara rinci dapat dilihat pada tabel berikut. 


\section{Alat dan Bahan}

Alat yang digunakan dalam penelitian ini yaitu cawan petri, alat gelas, neraca analitik, bunsen, hot plate dan magnetic stirrer, $\mathrm{pH}$ meter Merck, pipet, pinset, surgical blade scalpel, Laminar Air Flow (LAF), autoklaf, kamera Cannon, mikroskop, optilab viewer 2.2 dan SPSS 22. Bahan yang digunakan yaitu eksplan batang in vitro hasil perkecambahan biji kentang yang diperoleh dari perkebunan kentang di Wonosobo Jawa Tengah, alkohol 70\%, bayclean, fungisida, akuades, blue solvent, agar, media Murashigee \& Skoog with Vitamins-Caisson Laboratories inc, gula sukrosa, TDZ Merck, larutan HCL dan $\mathrm{NaOH}$.

\section{Prosedur Kerja}

Media penelitian dibuat dengan komposisi yaitu media Murashige \& Skoog (MS) 4,43g/L, sukrosa $30 \mathrm{~g} / \mathrm{L}$, TDZ 0, 4,5, 6, 7,5ppm, dan agar 8 $\mathrm{g} / \mathrm{L}$. Selanjutnya, batang in vitro dengan tunas (bagian nodus) dan tanpa tunas (bagian internodus) hasil perkecambahan biji dipotong secara melintang dengan panjang eksplan $1,5 \mathrm{~cm}$ menggunakan surgical blade scalpel. Eksplan batang in vitro bertunas dan tanpa tunas diinisiasi pada media MS dengan 4 perlakuan konsentrasi TDZ, yaitu 0ppm, 4,5ppm, 6ppm, dan 7,5ppm. Setiap media ditanam sebanyak lima eksplan. Penanaman eksplan dilakukan dalam keadaan steril didalam LAF (Laminar Air Flow). Kultur diinkubasi pada suhu $25^{\circ} \mathrm{C}$ dengan pencahayaan lampu 1000 lux. Kultur diamati setiap minggu selama 2 bulan menggunakan optilab dan kamera, kemudian dilakukan pengambilan gambar pada setiap eksplan yang ditanam.

\section{Analisis Data}

Parameter penelitian yang diamati antara lain persentase eksplan yang steril, persentase eksplan yang hidup, morfologi kalus embriogenik yang terbentuk, jumlah akar, jumlah tunas, dan jumlah daun. Persentase eksplan yang steril dan hidup dihitung dengan rumus sebagai berikut :
Persentase eksplan steril :

$$
\frac{\text { eksplan steril }}{\text { total eksplan semua perlakuan }} \times 100 \%
$$

Persentase eksplan hidup :

$$
\frac{\text { eksplan hidup }}{\text { total eksplan semua perlakuan }} \times 100 \%
$$

Data kuantitatif yang didapat dianalisis secara statistik menggunakan Analysis of Variance (ANOVA). Jika terdapat perbedaan nyata, dilakukan uji lanjut menggunakan Uji DMRT (Duncan's Multiple Range Test) dengan taraf signifikansi $95 \%$ untuk mengetahui perbedaan pada semua perlakuan.

\section{HASIL DAN PEMBAHASAN}

\section{Sterilitas dan Viabilitas Eksplan}

Penelitian tentang "Respon Organogenesis Eksplan Batang Kentang terhadap Perlakuan Konsentrasi TDZ" menghasilkan persentase eksplan steril dan persentase eskplan hidup yang berbeda pada setiap perlakuan. Sterilitas eksplan tertinggi adalah perlakuan B1T0 dengan rataan nilai $100 \%$ (Tabel 1). Perlakuan B1T0 juga memiliki viabilitas eksplan terbaik dengan rataan nilai eksplan hidup 100\% (Tabel 1). Perlakuan B0T7,5 memiliki persentase eksplan steril dan eksplan hidup paling rendah dibandingkan perlakuan lainnya. Peningkatan konsentrasi TDZ cenderung mengurangi persentase eksplan steril dan persentase eksplan hidup. Hal ini didukung oleh pendapat Wartina (2016) bahwa ZPT yang digunakan secara berlebihan akan menghambat morfogenesis tanaman. Eksplan yang hidup memiliki jaringan yang tidak rusak, warna eksplan hijau segar atau hijau kekuningan serta aktif merespon media dan terjadinya perubahan bentuk eksplan (Gambar $1 \mathrm{C}$ ). Hal ini sesuai dengan pendapat Rodinah, et al., (2016) yang menyatakan bahwa eksplan dikatakan hidup apabila media tidak terkontaminasi dan eksplan mengalami perubahan bentuk maupun tidak. 
Tabel 1. Rata - rata persentase eksplan steril, persentase kontaminasi eksplan, persentase eksplan hidup, dan persentase eksplan mati setiap perlakuan pada 60 hari setelah tanam (HST).

\begin{tabular}{lcccc}
\hline Perlakuan & $\begin{array}{c}\text { Persentase } \\
\text { eksplan steril } \\
(\%)\end{array}$ & $\begin{array}{c}\text { Persentase } \\
\text { kontaminasi } \\
\text { eksplan }(\%)\end{array}$ & $\begin{array}{c}\text { Persentase } \\
\text { eksplan hidup } \\
(\%)\end{array}$ & $\begin{array}{c}\text { Persentase } \\
\text { eksplan mati } \\
(\%)\end{array}$ \\
\hline B0T0 & $95 \%$ & $5 \%$ & $90 \%$ & $10 \%$ \\
B1T0 & $100 \%$ & $0 \%$ & $100 \%$ & $0 \%$ \\
B0T4,5 & $95 \%$ & $5 \%$ & $80 \%$ & $20 \%$ \\
B1T4,5 & $95 \%$ & $5 \%$ & $90 \%$ & $10 \%$ \\
B0T6 & $90 \%$ & $10 \%$ & $70 \%$ & $30 \%$ \\
B1T6 & $90 \%$ & $10 \%$ & $85 \%$ & $15 \%$ \\
B0T7,5 & $80 \%$ & $20 \%$ & $60 \%$ & $40 \%$ \\
B1T7,5 & $85 \%$ & $15 \%$ & $80 \%$ & $20 \%$ \\
\hline K17
\end{tabular}

Keterangan :

B0T0 = Batang tanpa tunas, TDZ 0ppm B0T4,5 = Batang tanpa tunas, TDZ 4,5ppm B0T6 = Batang tanpa tunas, TDZ 6ppm B0T7,5 = Batang tanpa tunas, TDZ 7,5ppm

Eksplan yang steril mengindikasikan bahwa sterilisasi yang dilakukan berhasil (Gambar $1 \mathrm{~A}$ ). Menurut Suliansyah (2013) Sterilisasi eksplan yang bebas kontaminasi merupakan langkah awal dalam keberhasilan kultur jaringan. Hasil penelitian menunjukkan bahwa kontaminasi muncul dengan waktu yang beragam (Gambar 1 B). Waktu terjadinya kontaminasi bervariasi mulai dari 7 HST sampai dengan 20 HST. Kultur yang terkontaminasi memiliki permukaan media yang berwarna putih, kuning, hijau, atau kelabu hitam, berlendir, dan berbau busuk. Hal ini sesuai dengan pendapat Shofiyani dan Damajanti (2015) bahwa sumber kontaminasi yang disebabkan oleh bakteri menunjukkan ciri-ciri terbentuknya lapisan lendir berwarna putih atau putih kecoklatan di bagian permukaan media. Kontaminasi yang disebabkan oleh jamur menunjukkan ciri-ciri terbentuknya lapisan hifa berwarna putih atau putih kelabu hitam di permukaan media. Kontaminasi pada kultur disebabkan oleh sterilisasi alat yang kurang optimal, keberadaan tetes air pada media, sumber eksplan dan kurang rapatnya plastic wrap dalam menutup petri. Media yang disterilisasi pada autoklaf dan diletakkan di bawah penyinaran lampu menyebabkan terjadinya pengembunan. Hal ini menyebabkan kontaminan mudah masuk dan tumbuh pada media kultur.

Kematian eksplan pada penelitian ini terjadi pada eksplan batang bertunas maupun batang tanpa
B1T0 = Batang bertunas, TDZ 0ppm

B1T4,5 = Batang bertunas, TDZ 4,5ppm

B1T6 = Batang bertunas, TDZ 6ppm

B1T7,5 = Batang bertunas, TDZ 7,5ppm

tunas (Gambar 1 D). Eksplan yang mati memiliki warna coklat tua, bertekstur kering, dan muncul eksudat di bawahnya. Kematian eksplan umumnya disebabkan karena pelukaan eksplan yang berlebih, browning, ZPT yang tinggi, umur eksplan yang tua, perendaman alkohol dan lingkungan in vitro yang tidak sesuai. Hasil pengamatan menunjukkan bahwa kematian eksplan kebanyakan disebabkan karena browning atau pencoklatan dan penggunaan TDZ berkonsentrasi 7 ppm yang diduga meracuni eksplan. Perendaman alkohol yang terlalu lama juga dapat menyebabkan eksplan mengalami browning. B0T7,5 memiliki persentase eskplan mati tertinggi (40\%) dikarenakan terjadinya browning dan penuaan sel yang lebih cepat, akibat ketidakmampuan adaptasi terhadap perlakuan TDZ yang diberikan. Menurut Admojo dan Indrianto (2016) browning dapat terjadi karena adanya penumpukan senyawa fenolik pada media akibat dari pelukaan organ. Hal ini didukung oleh Rahmawati dan Lukmana (2018) bahwa browning merupakan tanda terjadinya kemunduran fisiologis eksplan dan sintesis senyawa fenol. Pencoklatan disebabkan oleh semakin bertambahnya umur sel dan jaringan pada eksplan. Jenis eksplan batang bertunas cenderung meningkatkan viabilitas (daya hidup) dan persentase eksplan hidup daripada eksplan batang tanpa tunas, sedangkan peningkatan konsentrasi TDZ cenderung menurunkan viabilitas dan persentase eksplan hidup. 


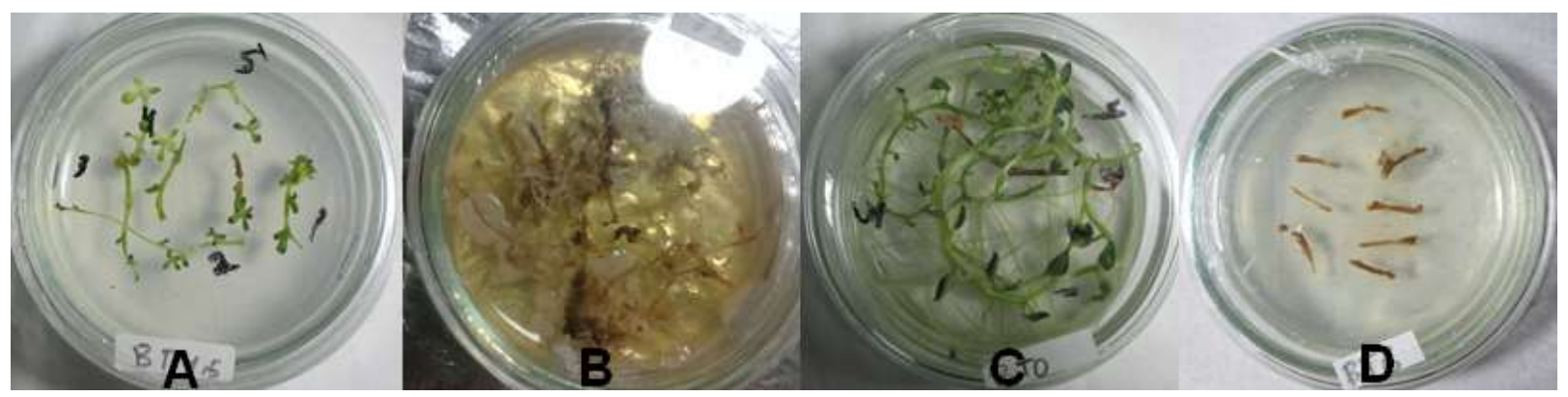

Gambar 1.Perbandingan kondisi eksplan setelah diinisiasi.

A. Eksplan Steril, B. Eksplan Terkontaminasi, C. Eksplan Hidup, D. Eksplan Mati.

\section{Jumlah Tunas}

Hasil uji ANOVA pada perlakuan jenis eksplan berbeda dan konsentrasi TDZ berpengaruh nyata terhadap jumlah tunas. Tidak ada interaksi antara perlakuan jenis eksplan dan konsentrasi TDZ terhadap jumlah tunas. Hasil uji Duncan terhadap jumlah tunas menunjukkan perbedaan yang nyata pada semua perlakuan konsentrasi TDZ. Hasil penelitian menunjukkan perlakuan terbaik untuk jumlah tunas (Gambar 1) adalah B1T4,5 dengan tunas berjumlah 7,83. Jumlah tunas pada B0T0 dan B1T0 memiliki nilai terendah, namun tunas yang tumbuh cenderung lebih panjang. Hal ini disebabkan karena tidak adanya penambahan TDZ pada media kontrol dan kandungan auksin endogen kentang yang tinggi, sehingga memacu elongasi atau pemanjangan sel di bagian meristem pucuk. Hal ini sesuai dengan pernyataan Orkun and Sema (2011) bahwa perlakuan kontrol yang perkembangan tunasnya lebih lambat dari perlakuan lain, mengindikasikan bahwa jaringan yang mudah membentuk tunas adalah jaringan yang sensitif terhadap perlakuan zat pengatur tumbuh. Hal ini didukung oleh Schepetilnikov dan Ryabova (2017) bahwa auksin akan mendegradasi represor Aux/IAA dan mengaktifkan enzim ubiquitin ligase. Enzim ubiquitin ligase meningkatkan konsentrasi Auxin Respon Factor (ARF) sehingga menyebabkan elongasi atau pemanjangan tunas. B0T7,5 dan B1T7,5 menghasilkan jumlah tunas yang lebih banyak (Gambar 1) daripada B0T0 dan B1T0, namun tunas yang terbentuk lebih pendek. Menurut Anjarsari, et al., (2012) penambahan sitokinin eksogen yang terlalu tinggi menyebabkan terhambatnya pemanjangan tunas. Hal ini didukung oleh pendapat Stepanova dan Alonso (2011) bahwa aktivasi protein ARR1 tipe B oleh sitokinin menyebabkan ekspresi gen SHY2 / IAA3 berupa penurunan konsentrasi transporter mRNA PIN1 dan respon auksin yang negatif, sehingga kerja auksin dalam meningkatkan panjang tunas terganggu.

Penambahan TDZ sebanyak 4,5ppm paling efektif dalam memacu perbanyakan tunas secara cepat dan banyak (Gambar 1). Peningkatan konsentrasi TDZ sampai 4,5ppm akan meningkatkan jumlah tunas yang terbentuk, sedangkan konsentrasi lebih tinggi menyebabkan penurunan jumlah tunas, namun tetap lebih tinggi daripada kontrol. Kumar, et al., (2011) menyebutkan bahwa persentase induksi tunas dan jumlah tunas per eksplan berbanding lurus dengan konsentrasi TDZ. Persentase induksi tunas $(66,97 \%)$ dan jumlah tunas per eksplan $(13,76)$ tertinggi diperoleh pada TDZ 9,08 $\mu \mathrm{M}$. Hal ini didukung oleh Lipavska, et al., (2011) bahwa penambahan sitokinin (TDZ) akan meningkatkan konsentrasi CDK aktif sehingga menyebabkan pembelahan sel secara cepat dan meningkatkan jumlah tunas secara efektif. Lestari (2011) menyatakan bahwa sitokinin digunakan untuk merangsang faktor multiplikasi atau perbanyakan tunas yang tinggi. Penggunaan eksplan batang bertunas (nodus) dan peningkatan konsentrasi TDZ cenderung meningkatkan jumlah tunas di semua perlakuan daripada perlakuan kontrol (B0T0). Hal ini dikarenakan keberadaan tunas dengan kombinasi sitokinin berupa TDZ dapat memacu sel sel untuk membentuk tunas baru yang lebih banyak. Deepak, et al., (2019) menyatakan eksplan nodus atau tunas memiliki nilai efisiensi regenerasi pertumbuhan $46.66 \%$ pada TDZ 0,1 ppm. 
Penambahan TDZ lebih tinggi (B0T6, B1T6, B0T7,5, dan B1T7,5) menyebabkan warna tunas yang terbentuk menjadi hijau pucat (Gambar $3 \mathrm{C}$, D), sedangkan tunas B0T0, B1T0, B0T4,5, dan B1T4,5 masih memiliki warna hijau terang (Gambar 3 A, B). Konsentrasi TDZ yang tinggi dapat mengganggu proses pembentukan klorofil dan fotosintesis. George, et al., (2008) menyatakan pemberian sitokinin secara tunggal mampu menghasilkan tunas yang maksimal, namun pada konsentrasi tertentu akan menghasilkan kelainan pada tunas yang terbentuk.

\section{- Batang Tanpa Tunas Batang Bertunas}

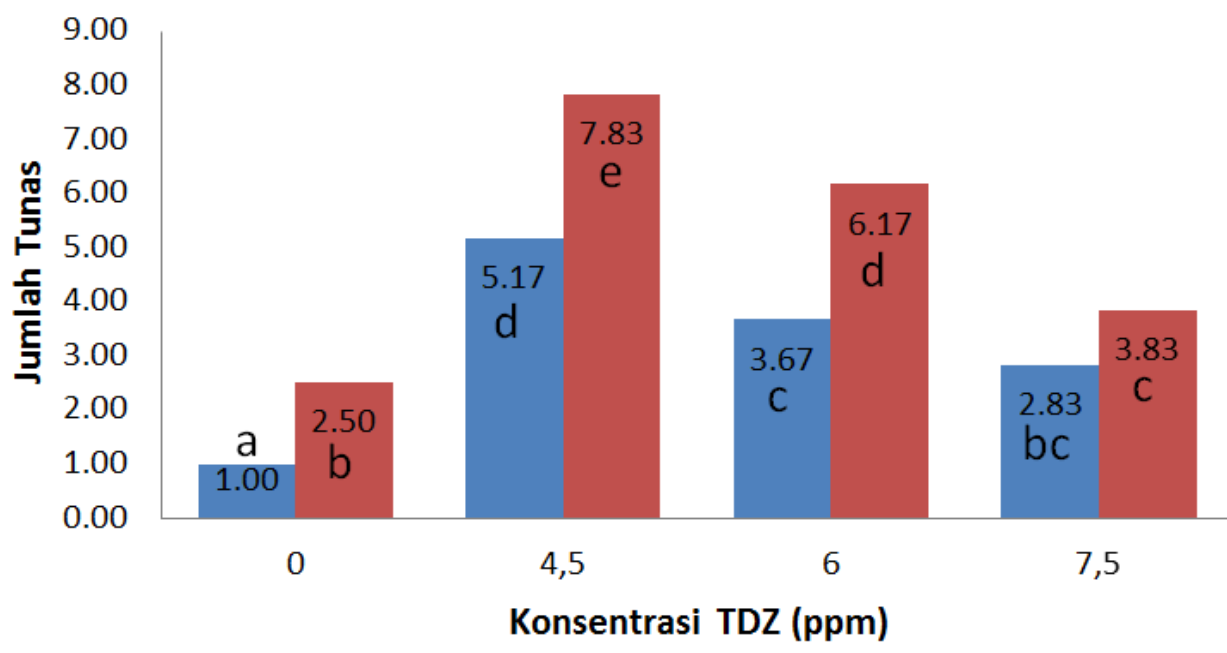

Gambar 2. Histogram rerata jumlah tunas umur 8 minggu setiap perlakuan
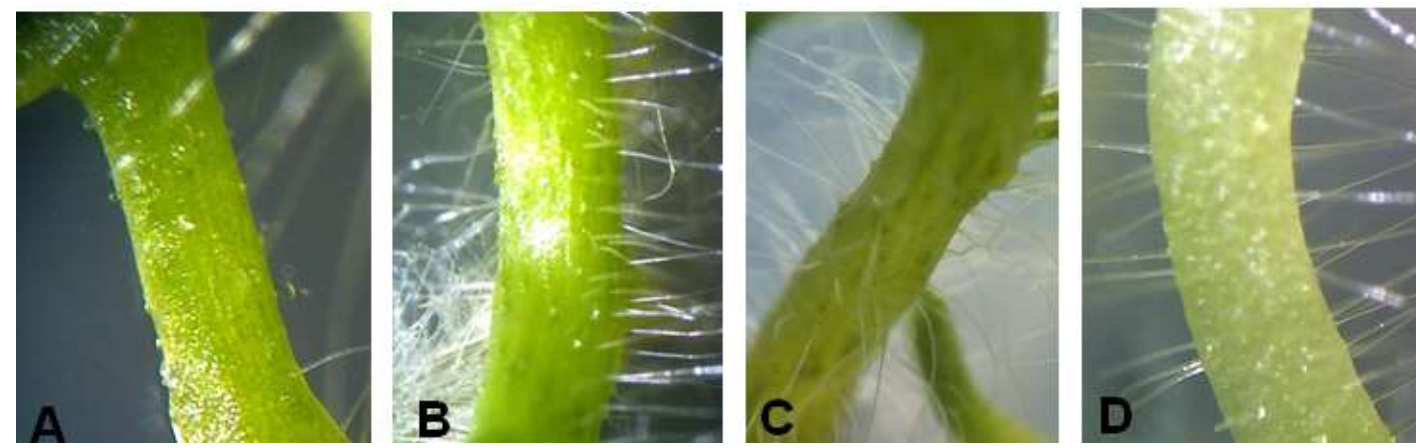

Gambar 3. Perbandingan Warna Tunas Konsentrasi TDZ Berbeda

A. TDZ 0ppm, B. TDZ 4,5ppm, C. TDZ 6ppm, D. TDZ 7,5ppm

\section{Jumlah Daun}

Hasil uji ANOVA pada perlakuan jenis eksplan berbeda dan konsentrasi TDZ berpengaruh nyata terhadap jumlah daun. Hasil uji Duncan terhadap jumlah daun menunjukkan perbedaan yang nyata pada semua perlakuan konsentrasi TDZ. Ada interaksi antara perlakuan jenis eksplan dan konsentrasi TDZ terhadap jumlah daun. Peningkatan konsentrasi TDZ sampai 6ppm akan meningkatkan jumlah daun yang terbentuk, sedangkan TDZ 7,5ppm mengalami penurunan jumlah daun. Hal ini dikarenakan pengaruh auksin endogen dan TDZ yang berperan dalam proses pembentukan daun. Keberadaan tunas dalam eksplan juga meningkatkan pembentukan daun.

Hasil penelitian menunjukkan perlakuan terbaik untuk jumlah daun adalah B1T4,5 yang berjumlah 38,33 (Gambar 4). B0T7,5 memiliki jumlah daun terendah karena penambahan TDZ yang tinggi dan tidak adanya tunas sehingga pembentukan daun kurang maksimal. Daun yang terbentuk pada B0T0, B1T0, B0T4,5, dan B1T4,5 memiliki warna hijau. Perlakuan B0T6 dan B1T6 memiliki daun berwarna hijau kekuningan, sementara perlakuan B0T7,5 dan B1T7,5 memiliki 
daun berwarna kuning pucat. Semakin tinggi konsentrasi TDZ cenderung memperkecil ukuran daun. Batang pada semua perlakuan penambahan TDZ memiliki ruas ruas (internodus) yang cenderung pendek dan memiliki buku buku (nodus) yang lebih banyak. Pertumbuhan daun menjadi lebih cepat dan lebih banyak akibat pemendekan ruas (internodus), sehingga daun tampak rapat dan padat. Hal ini didukung oleh Pratama, et al., (2014) bahwa pemendekan dan rapatnya ruas ruas batang (internodus) dipengaruhi oleh penambahan sitokinin berkonsentrasi tinggi. Menurut Stepanova dan Alonso (2011) sitokinin menginduksi peningkatan konsentrasi protein ARR sehingga meningkatkan ekspresi gen (respon sitokinin yang positif) utnuk mempercepat pembentukan daun. Sitokinin juga menyebabkan ekspresi gen SHY2 / IAA3 berupa respon auksin yang negatif, sehingga mengganggu peran auksin dalam memacu pemanjangan (elongasi) batang.

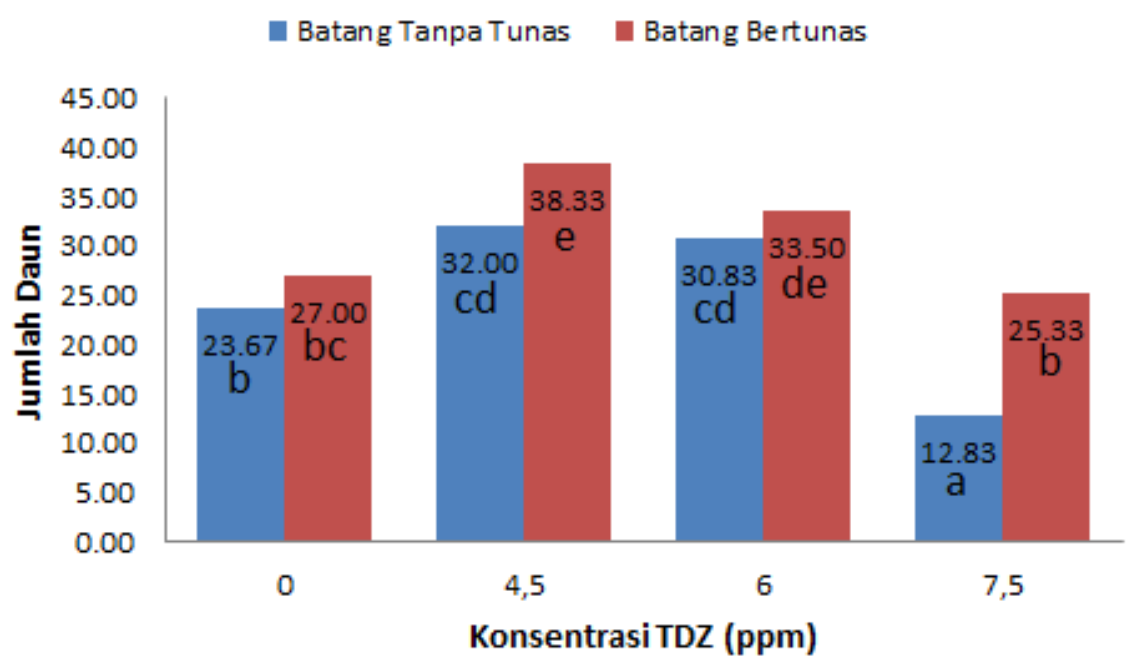

Gambar 4. Histogram rerata jumlah daun umur 8 minggu setiap perlakuan.

Perlakuan kontrol (B0T0 dan B1T0) kurang efektif dalam membentuk daun dibandingkan TDZ 4,5ppm dan 6ppm (Gambar 4), karena tidak adanya sitokinin eksogen yang membantu kerja auksin endogen dalam membentuk daun. Sari, et al., (2014) menyatakan bahwa penambahan konsentrasi sitokinin dapat mendorong pembelahan sel melalui proses metabolisme dan pada akhirnya membentuk tunas-tunas baru. B0T7,5 dan B1T7,5 memiliki jumlah daun yang lebih sedikit dibanding perlakuan lainnya, karena konsentrasi TDZ yang ditambahkan terlalu tinggi dan diduga meracuni tanaman dan mengganggu kinerja auksin endogen dalam pembentukan daun. B0T4,5, B1T4,5, B0T6, dan B1T6 memiliki pertumbuhan daun yang optimal, karena penambahan konsentrasi TDZ yang tepat untuk mempercepat pembelahan sel dan pembentukan daun. Hal ini didukung oleh pendapat Stepanova dan Alonso (2011) bahwa sitokinin diikat oleh reseptor AHK2, AHK3 dan CRE1, dan menyebabkan auto-fosforilasi sehingga gugus fosfat ditransfer ke protein AHPs. Selanjutnya protein AHPs ditranslokasi ke nukleus untuk fosfoforilasi protein ARR (Arabidopsis Response Regulators). Peningkatan konsentrasi protein ARR akan meningkatkan ekspresi gen (respon sitokinin yang positif), sehingga pembentukan daun lebih cepat. Menurut Hirose, et al. (2008) untuk membentuk daun, eksplan membutuhkan sitokinin sebagai bahan dasar pemacu pembelahan sel untuk pembentukan daun yang ditranslokasikan oleh akar.

\section{Jumlah Akar}

Hasil uji ANOVA pada perlakuan jenis eksplan berbeda dan konsentrasi TDZ berpengaruh nyata terhadap jumlah akar. Hasil uji Duncan terhadap jumlah akar menunjukkan perbedaan yang nyata pada semua perlakuan konsentrasi TDZ. Tidak ada interaksi antara perlakuan jenis eksplan dan konsentrasi TDZ terhadap jumlah akar.

Peningkatan konsentrasi TDZ menurunkan jumlah akar yang terbentuk, karena mengganggu 
kinerja auksin endogen pada eksplan dalam pembentukan akar. Penggunaan eksplan batang bertunas meningkatkan jumlah akar di semua perlakuan daripada eksplan batang tanpa tunas. Hal ini dikarenakan keberadaan tunas (mengandung auksin endogen lebih tinggi) dapat memacu sel sel meristem untuk membentuk akar lebih cepat. Hal ini sesuai dengan Das, et al., (2018) bahwa semakin tinggi konsentrasi auksin maka induksi akar semakin efektif. Hal ini didukung oleh Schepetilnikov dan Ryabova (2017) bahwa auksin akan mengaktifkan enzim ubiquitin ligase Skp1Cullin-F-box $(\mathrm{SCF})^{\mathrm{TIR} 1}$ yang berkaitan dengan protein F-box TIR1 di membran plasma. Protein Fbox TIR1 mengikat represor transkripsi Aux/IAA dan menyebabkan degradasi Aux/IAA. Selanjutnya, protein F-box TIR1 menyebabkan respon transkripsi dan mengaktifkan Auxin Response Factor (ARF). Transkripsi ARF yang tinggi meningkatkan ekspresi gen untuk perkembangan tanaman, sehingga pembentukan akar dari meristem lebih cepat. Perlakuan kontrol (B0T0 dan B1T0) memiliki akar dan tunas tumbuh memanjang, sehingga tampak rapat di petri karena pertumbuhannya mengelilingi petri. Perlakuan konsentrasi TDZ mempengaruhi pola pertumbuhan yang terfokus pada multiplikasi tunas, sehingga planlet memiliki tunas yang pendek. Hal ini didukung oleh Pratama, et al., (2014) bahwa pemendekan dan rapatnya ruas ruas batang (internodus) dipengaruhi oleh penambahan sitokinin berkonsentrasi tinggi

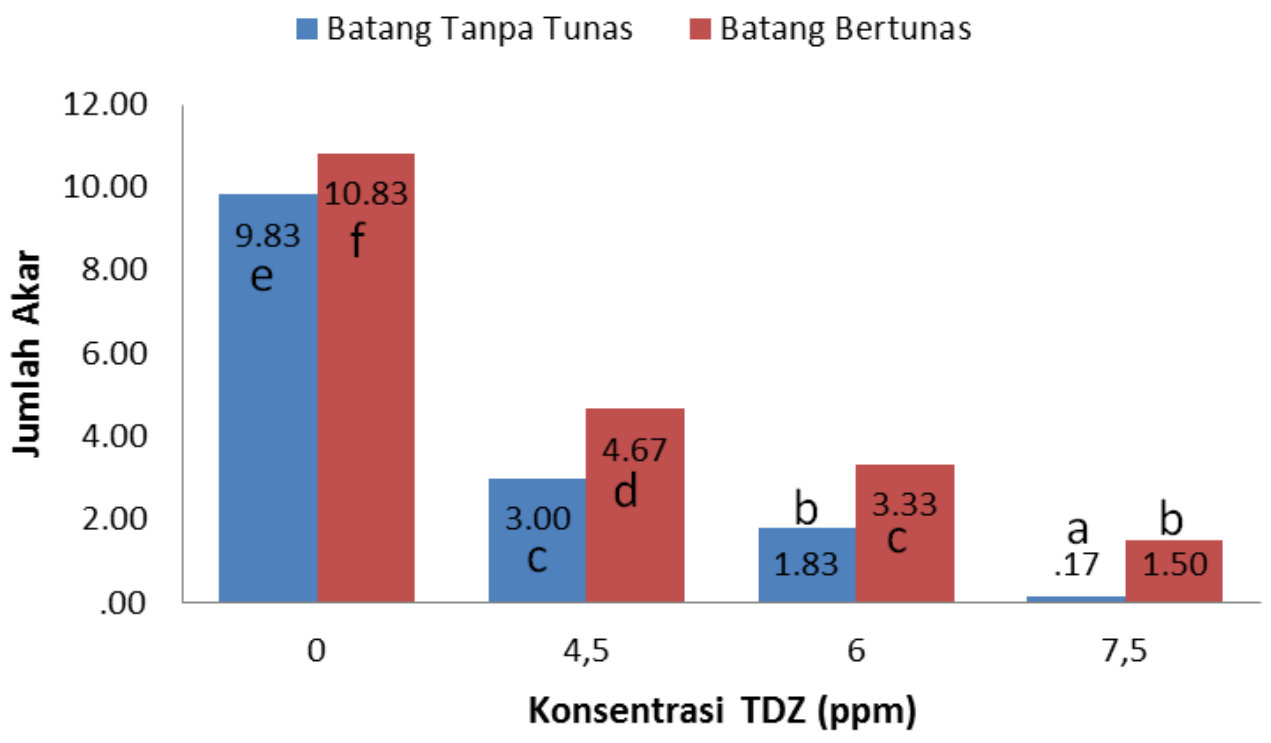

Gambar 5. Histogram rerata jumlah akar umur 8 minggu semua perlakuan

\section{KESIMPULAN}

Jenis eksplan batang bertunas cenderung meningkatkan viabilitas dan persentase eksplan hidup daripada eksplan batang tanpa tunas, sedangkan peningkatan konsentrasi TDZ cenderung menurunkan viabilitas dan persentase eksplan hidup. Jenis eksplan dan konsentrasi TDZ mempengaruhi secara nyata jumlah tunas, daun dan akar. Tidak ada interaksi antara perlakuan jenis eksplan dan konsentrasi TDZ terhadap jumlah tunas dan akar, tetapi ada interaksi yang nyata terhadap jumlah daun.

\section{DAFTAR PUSTAKA}

Admojo, L., dan Indrianto, A. 2016. Pencegahan Browning Fase Inisiasi Kalus Pada Kultur Midrib Daun Klon Karet (Hevea brasiliensis) PB 330. Indonesian Journal of Natural Rubber Research, 34 (1): 25-34.

Anjarsari, I. R. D., Nuraini A. dan Suminar E. 2012. Pengembangan Benih Unggul Nilam In vitro Serta Penguji Stabilitas Genetik di Lapangan Bedasarkan Marta Morfologi dan Molekuler. Bandung : PDII-LIPI. 
Aprilia, M. 2019. Perkembangan Kalus Tanaman Kentang (Solanum tuberosum L.) pada Media MS dengan Konsentrasi Benzyl Adeno Purin (BAP) yang Berbeda secara In Vitro. SKRIPSI. Semarang: Departemen Biologi, Fakultas Sains dan Matematika, Universitas Diponegoro.

Bhatia, S., Bera, T., Dahiya, R. dan Sharma, K. 2015. Modern Applications of Plant Biotechnology in Pharmaceutical Sciences. New Delhi: Academic Press is an imprint of Elsevier.

Bilal, B. G., Amir, H. A., L, Z., L. X., dan Y, H. W. 2011. Thidiazuron: A multidimensional plant rowth regulator. African Journal of Biotechnology, 10 (45): 89849000. https://doi.org/10.5897/ AJB11.636

Das, P., Tanti, B., Borthakur, S. K. 2018. Callus Induction and Indirect Organogenesis of Brucea mollis Wall. Ex Kurz - A Potential Medicinal Plant of Northeast India. South African Journal of Botany, 119: 203-211.

Darini, M. T. 2012. Efektivitas Sterilisasi dan Efisiensi Media Murashige Skoog terhadap Pertumbuhan Eksplan Lidah Buaya. Agrineca, 12 (2).

Deepak, K.V., Ivin, J. J. S., Narayanan, G. S., Prakash, M., Murugan, S., Anandan, R. 2019. Efficient plant regeneration and histological evaluations of regenerants through organogenesis and somatic embryogenesis in Spermacoce hispida L.An underutilized medicinally important plant. Industrial Crops \& Products, 134 (2019): 292-302.

Fauzi , M. I.,Yelli, F., Edy, A., Utomo, S. D. 2014. Regenerasi In Vitro Empat Varietas Kedelai (Glycine max [L.] Merr.) melalui Organogenesis menggunakan Eksplan Biji yang Diimbibisi dan Dikecambahkan. $J$. Agrotek Tropika, 2 ( 2): 252-257.

George, F. E., A, Hall M., dan Jan De Clerk. 2008. Plant Propagation by Tissue Culture. 3rd ed. The Netherlands : Springer.

Hirose, N., K. Takei., T. Kuroha1., N. T. Kamada., H. Hayashi dan H. Sakakibara. 2008. Regulation of Cytokinin Biosynthesis,
Compartmentalization and Translocation. Journal of Experimental Botany, 59: 75-83.

Karjadi, A. K., dan A. Buchory. 2008. Pengaruh Auksin dan Sitokinin terhadap Pertumbuhan dan Perkembangan Jaringan Meristem Kentang Kultivar Granola. Jurnal Hortikultura. 18 (4): 380-384.

Kumar, N., Vijayanand, K. G., Reddy, M. P. 2011. In Vitro Regeneration from Petiole Explants of Non-Toxic Jatropha curcas. Ind. Crops Prod, 33: 146-151.

Lestari, E. G. 2011. Peranan Zat Pengatur Tumbuh dalam Perbanyakan Tanaman melalui Kultur Jaringan. AgroBiogen. 7 (1): 63-68.

Lipavska, H., Maskova, P., dan Vojvodova, P. 2011. Regulatory Dephosporylation of CDK at G2/M in Plant: Yeast Mitotic Phospatase CDC25 Induces Sitokinin-like Effect in Transgenic Tobacco Morphogenesis. Annals of Botany Journal, 107 (7): 10711086.

Orkun dan Sema. 2011. Induction of Salt-Tolerant Potato (Solanum tuberosum L.) Mutants with Gamma Irradiation and Characterization of Genetic Variations via RAPD-PCR Analysis. Turk J Biol., 36: 405412.

Pratama, A. R. N., Sugiyono, Prayoga, L., dan Husni, A. 2014. Upaya Memacu Pertumbuhan Tunas Mikro Kentang Kultivar Granola dengan Jenis dan Konsentrasi Sitokinin Berbeda. Scripta Biologica, 1 (3): 209.

Rahmawati, L., dan Lukmana, M. 2018. Respon Eksplan Daun Karet dalam Media WPM dengan Penambahan 2,4-D pada Berbagai Perlakuan Lama Perendaman Sterilisasi. Jurnal Budidaya Tanaman Perkebunan Politeknik Hasnur, 4 (2): 1 - 5.

Rodinah, F., Razie, D., Naemah, dan A. Fitriani. 2016. Respon Bahan Sterilan pada Eksplan Jelutung Rawa (Dyra lowii). Jurnal Hutan Tropis, 4 (3): $240-245$.

Sari, D. A., Slameto, Restanto, D. P. 2014. Induksi Tunas Kentang (Solanum tuberosum L.) 
Menggunakan BAP (Benzil Amino Purine). Berkala Ilmiah Pertanian, 1 (1) : 20-24.

Schepetilnikov, M., dan Ryabova, L. A. 2017. Auxin Signaling in Regulation of Plant Translation Reinitiation. Frontiers in Plant Science, 8 (1014): 1-15.

Shofiyani, A., dan Damajanti, N. 2015. Pengembangan Metode Sterilisasi pada Berbagai Eksplan Guna Meningkatkan Keberhasilan Kultur Kalus Kencur (Kaemferia galanga L). Agritech, 17 (1): 55 -64 .

Stepanova, A. N., dan Alonso, J. M. 2011. Bypassing Transcription: A Shortcut in Cytokinin-Auxin Interactions. Developmental Cell, 21: 608-610.

Sujjaritthurakarn, P., dan Kanchanapoom, K. 2011. Efficient Direct Protocorm-Like Bodies Induction of Dwarf Dendrobium using Thidiazuron. Notulae Scientia Biologicae, 3 (4): 88-92. https://doi.org/10.15835/NSB346356Y

Suliansyah, I. 2013. Kultur Jaringan Tanaman. Yogyakarta : LeutikaPrio.

Wartina, R. 2016. Pengaruh NAA dan BAP terhadap Regenerasi Kalus Kentang (Solanum tuberosum L.) Hasil Induksi Mutasi Ethyl Methane Sulphonate (EMS). Jurnal Tanaman Hortikultura, 1-8.

Winarto, B., Mattjik, N., Purwito, A., dan Marwoto, B. 2010. Aplikasi 2,4-D dan TDZ dalam Pembentukan dan Regenerasi Kalus pada Kultur Anther Anthurium. Jurnal Hortikultura, 20 (1): 1-9.

Yuwono, T. 2019. Bioteknologi Pertanian. Yogyakarta: Gadjah Mada University Press. 